\title{
Death in the Aljama of Huesca: the Jews and Royal Taxation in Fourteenth-Century Aragon ${ }^{*}$
}

\author{
Alexandra Guerson ** \\ New College, University of Toronto
}

\begin{abstract}
Muerte en la aljama de Huesca: los Judíos y los tributos ReAles en El aragón del SIGLO XIV.- En 1385, el judío Baruch Alentienz fue asesinado por miembros de la aljama judía mientras ejercía la función de tesorero en la comunidad judía de Huesca. Este artículo analiza el asesinato de Baruch en el contexto del crecimiento de la presión tributaria sobre las comunidades mediterráneas -tanto cristianas, como judías y musulmanas-en el siglo XIV. Como tercera comunidad judía más grande del reino de Aragón, la aljama de Huesca era responsable del $18 \%$ del total de contribuciones tributarias demandadas por la Corona a los judíos aragoneses. El caso de Baruch Alentienz nos ofrece una oportunidad única para explorar la historia fiscal y económica del Reino de Aragón y demuestra cómo el desarrollo del sistema fiscal y el crecimiento tributario del estado derivó en muchos conflictos internos en las comunidades locales.
\end{abstract}

Palabras clave: Historia de los judíos; tributos; conflicto en la comunidad judía; siglo XIV; violencia; Aragón; adelantados; clavarios.

In 1385, Baruch Alentienz was beaten to death by fellow Jews while exercising his duties as treasurer of the Jewish community of Huesca. This article analyzes Baruch's murder in the context of the growing fiscal pressures imposed on communities - whether Christian, Jewish, or Muslim - throughout the Mediterranean in the fourteenth century.

\footnotetext{
" The Social Sciences and Humanities Council of Canada provided the funds for the research behind this article. An earlier version was presented at the Colloquium on The Medieval and Early Modern Mediterranean: New Approaches at the Centre for Medieval Studies, University of Toronto, on 18 April 2011. I am grateful to Mark Meyerson, Dana Wessell Lightfoot, Barbara Todd, Frances Timbers, and the anonymous reviewer from Sefarad for their helpful criticism. Any errors remain my own.

**a alexandra.guerson@utoronto.ca
} 
With the third largest Jewish community of the kingdom of Aragon and being responsible for $18 \%$ of the total contributions expected by the Crown from the Jews of Aragon, Huesca provides us with an ideal case study of these larger patterns. The case of Baruch Alentienz gives us a unique opportunity to shed light on the fiscal and economic history of the kingdom of Aragon but perhaps more importantly, shows how this growing taxation led to growing conflict inside local communities.

KEYwords: History of the Jews; Taxes; Conflict in the Jewish community; $14^{\text {th }}$ century; Violence.

In 1385, Baruch Alentienz, the treasurer of the Jewish community of Huesca was beaten and stabbed to death by fellow Jews while exercising his duties as an official of the community. 'We know of Baruch's murder through a series of royal letters regarding the case. The letters contain few details about the actual murder - all we know is that Mosse Ablatronell and his son David were accused of murdering Baruch when he exercised his position as treasurer or tax collector (clavario) of the aljama. ${ }^{2}$ Mosse and David were identified earlier as renters of the rights of the butchery of the aljama. ${ }^{3}$ In the absence of actual trial records, the thirty-four letters dealing with Baruch Alentienz and his murder found in the royal chancery registers of Kings Pere the Ceremonious and Joan I, as well as over one hundred letters dealing with the Jewish community of Huesca, give us a unique opportunity to explore some of the tensions that existed

${ }^{1}$ In March of 1380, King Pere confirmed that Baruch was elected adelantado of the aljama the previous year, with a salary of 300s/year. See Archivo de la Corona de Aragón, serie Registros de Cancillería [hereafter ACA C] 810: 85v-86r (20/03/1380). Another Baruch Alentienz (spelled Alitienz) is mentioned in Eugenio Benedicto Gracia, "El asesinato en 1465 de Jehudá Alitienz, de la judería de Huesca,” Sefarad 65 (2005) pp. 287-325.

2 The first mention of the murder is described thus: "percepimus supplicatione humili lacrimabiliter nobis porrecta per parte açaqui Alentienz judei fratris baruch alantenç judei dicte Civitatis hiis diebus crudeliter interfecti quodam quidam iudei perditionis filii dei et nostri timore pospositis manus atroces in dictum baruch iniacendo ipsum nulli malum seu iniuriam inferentem in judaria ipsius Civitatis nequiter permerunt partes sui corporis lacerando." ACA C 844: 90r (03/02/1385). Later on, the murder is always described as having been committed while Baruch exercised his duties of clavario: "mortis perpetrate in persona baruch Alentienz iudei Civitatis Osce qui exercendo ut dicitur officium clavarie aljame ipsius Civitatis fuit nequiter interfectus de qua morte inculpatur Mosse et David abatronell" ACA C 851: 167v (20/06/1386).

\footnotetext{
3 ACA C 823: 12v (27/09/1381).
} 
within Jewish communities of the Crown of Aragon in the late fourteenth century.

A close look at the murder of Baruch Alentienz shows that the Jews of the Crown of Aragon were under enormous fiscal pressure and that this pressure had not only political and economic consequences but also was perceived by the Jews as a threat to their survival. That Baruch was at the centre of disputes over taxation within the aljama is clear from suits involving him both before and after his death. Beginning with the case of Huesca, this article will explore how growing fiscal pressures from King Pere the Ceremonious (1336-1387) and King Joan I (1387-1396) enhanced tensions both within Jewish communities of the Crown of Aragon as well as between Christians and Jews, compounding their growing debt in the late fourteenth century. Although the development and stabilization of a tax system in the fourteenth-century Crown of Aragon has received increasing attention of historians, much of these studies have been based on the much richer archives of Catalonia and Valencia. The case of Baruch Alentienz gives us a unique opportunity to explore the economic and fiscal history of Aragon in the fourteenth century.

As Mark Meyerson has described so poignantly, royal taxation shaped much of Jewish life, identity, and intra- and inter-communal relations in the medieval Crown of Aragon. ${ }^{4}$ As is well known, the status of Jewish communities in the Crown of Aragon was predicated on their fiscal relationship with the Crown - the Jews were part of the royal treasury, to which they contributed both ordinary and extraordinary taxes. Beginning with Jaume I (1213-1276), royal demands increased with each subsequent monarch and the pressure did not abate under Pere III and Joan I. As was the case in the kingdom of Valencia a few decades earlier, demands for taxes in Aragon and Catalonia fanned the fires of growing conflict between different Jewish aljamas as well as between aljamas and individual Jews. ${ }^{5}$ The growing debt of the Jewish community and royal efforts to ease some of this burden would also do much to complicate relations be-

${ }^{4}$ Mark D. Meyerson, Jews in an Iberian Frontier Kingdom: Society, Economy, and Politics in Morvedre, 1248-1391 (Boston: Brill, 2004) pp. 98ff.

5 For Valencia, see Meyerson, Jews, p. 100. 
tween Christians and Jews in the late fourteenth century. ${ }^{6}$ Since the Jews' fiscal servitude was so "elemental to their identity," as Meyerson put it, it is not surprising that disputes over taxation account for some of the fiercest conflicts among Jews in the 1380s. Behind much of the tension was the collective nature of the contributions the Crown expected from its Jewish communities - each aljama had a lump sum imposed upon it and its officials were in charge of collecting the contributions of each member above the age of fourteen. Whenever an individual got an exemption from the king in exchange for services or favours, or moved out of the aljama's jurisdiction, the amount the aljama ultimately had to produce remained the same, which meant an added stress on the remaining Jewish taxpayers. The murder of Baruch Alentienz in Huesca provides us with a glimpse at the kinds of issues aljama officials and taxpayers grappled with in the closing decades of the fourteenth century.

The political situation in Huesca had been tense for a number of years before Baruch's death. Although we do not know exactly when Baruch first became involved in aljama administration, we know he was already an executive official in the aljama (adelantado) in 1379 and that his reappointment in 1382 was marked by controversy. Normally, Jewish aljamas enjoyed a degree of autonomy similar to that of a municipality. This meant they held the privilege of being able to elect their own administrators and officials. In the case of Huesca, its latest royal charter dated to 1374 and among other privileges, the charter stipulated that the incumbent administration would appoint a board of electors to choose the new administration. ${ }^{7}$ But in 1382, King Pere cancelled the election and re-appointed Baruch as adelantado and clavario (treasurer) - his other letters and privileges notwithstanding. ${ }^{8}$ This happened amidst reports that bad administration of the aljama was causing many Jews to leave and that

${ }^{6}$ I explore this in more detail in my doctoral dissertation. See Alexandra E. P. Guerson De Oliveira, "Coping with Crises: Christian-Jewish Relations in Catalonia and Aragon, 1380-1391" (PhD diss., University of Toronto, 2012).

7 Antonio Durán Gudiol, La judería de Huesca (Zaragoza: Guara, 1984) pp. 52-55. The full text of the 1374 ordination can be found in pp. 147-153. The privileges issued by King Pere were confirmed by his son, King Joan, in 1391. See ACA C 1898: 196r-199v (06/03/1391).

8 ACA C 976: 63v-64v (26/06/1381). 
the aljama was at risk of being destroyed. In the previous year, the aljama of Huesca showed signs of being in a difficult economic position when it asked King Pere for a reprieve after it found itself unable to pay a censal it owed to Prince Martí. The details in King Pere's letters are vague but he seems to imply that he felt that re-appointing Baruch was the best way to stabilize the situation in the Jewish community.

Elections had been an issue in Huesca in the past. The first set of royal ordinances issued to the Jews of Huesca that are extant date from 1313 (Jaume II) and they established annual elections and set up the procedures for such events. For some reason, in 1324 the size of the electoral board was reduced from eighteen members to twelve. ${ }^{10}$ Later on, holding yearly elections became an issue and the 1374 ordinance, therefore, was issued in res-ponse to this plea. The new ordinance spaced out elections for every three years and entrusted the reigning adelantados with the choice of the twelve 'good men' who would act as a board of electors, as mentioned before. ${ }^{11}$

The elections of the adelantados were important events in a Jewish community since they performed a critical role within aljama administration. Also called secretaris in Catalonia, Perpignan and Mallorca, the adelantados were the executive branch of the Jewish community performing essential roles such as designation of other offices within the aljama, the management of economic matters, and the performance of certain judicial functions. ${ }^{12}$ In addition to the adelantados, an aljama

${ }^{9}$ ACA C 820: 97v-98r (28/03/1381).

10 Ricardo DEL ARCo, "La aljama judaica de Huesca," Sefarad 7:2 (1947) 271-301: 282; Durán Gudiol, La Judería de Huesca, p. 52. See ACA C 225: 280v (27/06/1324) in Jean RÉGNÉ, History of the Jews in Aragon: Regesta and Documents, 1213-1327 (Jerusalem: Magnes Press, 1979) p. 606 (\#3299).

11 ACA C 926: 39-41v; Durán Gudiol, La Judería de Huesca, pp. 147-153.

12 A document from Teruel in 1343 specified these roles: "Concedimus vobis judeis dicte aljame quod super quibuscumque causis seu questionibus quas inter judeum et judeum ipsius aliame super peccunia, deposituris seu comandis, possessionibus, patuis vel sedibus sinagogue suscitari contingat vobis facientibus juxta tecanam vel ritum judeorum justicie complementum conquerentibus coram adenantatis dicte aliame prout est fieri assuetum." David Romano, "Els Jueus de La Corona d'Aragó En Temps de Pere El Ceremoniós (1336-1387)," in Pere El Cerimoniós I La Seva Época (Barcelona: Institució Milá i Fontanals, 1989) pp. 113-131: 125. 
would also employ one to three clavaris, that is, treasurers who were responsible for collecting taxes and submitting them to the inspection of officials known as reebedors de comptes in Catalonia and Valencia, and oidores de cuentas in Aragon. ${ }^{13}$ The Aljama of Huesca employed two treasurers. Baruch Alentienz performed both the role of adelantado and clavario in Huesca, although it was in the exercise of his role as clavario, specifically, that he was killed.

Another factor that may help explain, in part, the political conflict in which Baruch found himself is the death of Queen Leonor in April 1375. King Pere had given to Queen Leonor the jurisdiction of the aljama of Huesca and since 1370, the queen routinely appointed the clavarios of the aljama. ${ }^{14}$ With her death in 1375 the aljama reverted back to the jurisdiction of King Pere. It is interesting to note that Baruch does not seem to be involved in aljama administration when it was under the jurisdiction of the queen. It is possible that in the transition from the jurisdiction of Queen Leonor to that of King Pere, Baruch represented a new faction coming into power.

Evidence from the royal chancery suggests that conflicts involving aljama officials continued throughout the 1380s, with their official actions becoming the source of long lasting enmity between individual Jews of the community of Huesca. This is particularly clear in the case of Baruch and his family. For about four to five years in the 1370 s, the positions of adelantado and treasurer of the aljama were occupied by Mosse Aburrabe and Sento el Castiell. For some reason, during that time, Baruch Alentienz and Juce Avenabeç had a disagreement with the adelantados over the amount of tax (peyta) they owed to the aljama and had refused to pay. The aljama officials would not take no for an answer and used their position to force Baruch and Juce to pay what they owed, which nei-

13 See Romano, "Els Jueus de La Corona d'Aragó," pp. 124-126; Yom Tov Assis, The Golden Age of Aragonese Jewry: Community and Society in the Crown of Aragon, 1213-1327 (London-Portland, OR: Vallentine Mitchell, 1997); Yitzhak BAER, A History of the Jews in Christian Spain (Philadelphia: Jewish Publication Society of America, 1992) vol. 1, pp. $212 \mathrm{ff}$.

${ }_{14}$ King Pere awarded the aljama of Huesca to his wife in 1360. See ACA C 903: 287v-288r (6/05/1360) and ACA C 1570: 3v-4r (25/04/1360). Cited in David Romano, "Los Surí, Judíos de Huesca y Perleros de La Reina de Aragón (1350-¿1372?)," Sefarad 40: 2 (1980) pp. 255-282: 257, nt. 9. 
ther Baruch nor Juce ever forgot or forgave. Mosse Aburrabe and Sento el Castiell later claimed that Baruch and Juce "hated them completely for it" ("eos odio totaliter...habuistis"). An opportunity to seek revenge presented itself when Mosse and Sento failed to file an account of their affairs at the end of their administration, as they were required to do. Instead of bringing up the issue within the community, Baruch and Juce did what their coreligionists did when they wanted to inflict the maximum amount of damage and expense on their enemies - they took the issue to the royal court. ${ }^{15}$ From the royal court, Juce and Baruch obtained a letter of commission reiterating their right to review the accounts of Mosse and Sento, who later claimed Baruch and Juce used the letter to harass them with many tasks and expenses. ${ }^{16}$

By-passing the aljama did not earn Baruch and Juce many friends. Baruch, particularly, continued to come into conflict with his fellow Jews as adelantado of the aljama. In 1380, Baruch complained to the king that "some" people had made unfounded accusations against him to the local inquisition and to the vice-governor. ${ }^{17}$ Although the scribe did not specify whether those accusing him were Jews or Christians, another letter issued on the same day by King Pere clarified that some Jews of the aljama of Huesca were harassing the treasurers of the aljama out of hatred for them. ${ }^{18}$ In response, King Pere ordered his officials and those of Prince Joan to restrain from interfering with the treasurers and to use their authority to support them in the exercise of their duties. He also reminded the bishops in charge of the inquisition of the king's sole jurisdiction over the Jews of his kingdom. ${ }^{19}$

Throughout the early years of the 1380s, Baruch managed to keep his enemies at bay by obtaining safe conducts from the king. In 1381 King Pere ordered the bailiff of Huesca to protect Baruch in the exercise of his duties as clavario against those "jealous people" acting out of "hatred" for

\footnotetext{
15 An upcoming article will deal with this issue in more depth.

16 ACA 815: 123v-124r (29/11/1380).

17 ACA C 810: 85v (20/03/1380).

18 ACA C 810: 85r-v (20/03/1380).

19 ACA C 810: 86r-v (20/03/1380).
} 
him. ${ }^{20}$ An official letter placing Baruch under royal protection, renewing a safe conduct that had earlier been issued and which was about to expire followed the letter to the bailiff. ${ }^{21}$ This particular letter of protection had no indication of a time limit. A week earlier, the Crown had issued a general protection to all Jews from Huesca, but "specially" for its officials. ${ }^{22}$ This did not completely protect Baruch, however, since in 1383 the royal court appointed a judge in Huesca to investigate the accusation that some local Jews were falsely accusing Baruch Alentienz of conspiracy. ${ }^{23}$

Royal protection, alas, was not enough and Baruch Alentienz was killed by fellow Jews in 1385. Although the details of the murder are not clear, nearly every single document that mentions his death specified that he was killed while performing his duties as treasurer or tax collector of the aljama. Mosse Ablatronell and his son David, Jews of Huesca, were accused of the crime. What might Mosse Ablatronell and his son David have had against Baruch? What was their relationship with the former adelantados of the aljama with whom Baruch had been in conflict earlier?

All we know about Mosse and David Ablatronell is that they earlier appeared in a list of Jews who held the right to exploit a very important utility, the butchery of the judería. ${ }^{24}$ Interestingly enough, Baruch's old enemies, Sento el Castiel and Mosse Aburrabe, were also listed, establishing a link between Baruch's murderers and his old rivals. In 1381, Mosse and David Ablatronell, Sento el Castiel, Mosse Aburrabe, and a few other Jews of the aljama were accused of employing a butcher who was not qualified to ritually slaughter animals, bringing into question the kosher nature of meat sold within the judería. At the time, the bailiff of Huesca was ordered to investigate the matter and although we have no further evidence involving this particular case, such an accusation would have caused quite a stir within the Jewish community. It is possible that Baruch was collecting fines related to this case when he was killed by

\footnotetext{
20 ACA C 823: $143 \mathrm{v}-144 \mathrm{r}(5 / 12 / 1381)$. Notice the use of very formulaic language.

21 ACA C 938: 253v-254r (05/12/1381).

22 ACA C 938: 254r-255r (29/11/1381).

23 ACA C 836: 127v (05/09/1383).

${ }^{24}$ ACA C 823: 12v (27/09/1381): "Arrendadorum iurium del Alquadem alias carniceria."
} 
Mosse and David Ablatronell or perhaps Baruch had initiated the suit as part of his conflict with Sento el Castiel and Mosse Aburrabe, compromising the reputation of all those in charge of the butchery for the aljama. A closer look at the fiscal problems facing the aljama suggests that Baruch's murder may have been the result of more than conflict among Jewish officials.

This is where the case of Baruch Alentienz intersects with the larger fiscal history of the Crown of Aragon and the consequences of that history for Jewish life there. As we know, all European states in the late Middle Ages went through a process of developing a taxation system meant to support their military ambitions as well as the cost of a growing state bureaucracy. Direct and indirect taxation would become key elements of royal policy throughout the fourteenth century. While there has been growing research in this area in recent years, as Carlos Laliena has recently pointed out, few scholars have explored in depth the social ramifications of these developments. ${ }^{25}$

For the Crown of Aragon, the general chronology of the development of its fiscal system is connected to the various wars of the period. In order to fund his conquest of Sardinia and conflict with Genoa (1321-1336), King Jaume II demanded more than 3 million sous from cities and aljamas in his kingdoms. Forty percent was supposed to be raised in Catalonia, thirty-five percent would come from Aragon and twenty-five percent from the Kingdom of Valencia. In order to be able to come up with such amounts, cities levied indirect taxes on consumption. The amounts required from municipalities were not modest. Between 1333-1335 the city of Daroca, for example, paid about 472,000s in contributions to the royal treasury, the equivalent of 100s per family (an amount sufficient

${ }^{25}$ One exception is the study conducted by Jeff Paul of the city of Manresa in Catalonia during the 1350s and 1360s. See Jeffrey Fynn-Paul, "Civic debt, civic taxes, and urban unrest: a Catalan key to interpreting the late fourteenth-century European crisis," in Money, Markets and Trade in Late Medieval Europe: Essays in Honour of John H.A. Munro, ed. Lawrin D. Armstrong, Ivana Elbl, and Martin Elbl (LeidenBoston: Brill, 2007); Jeffrey PAUL, The Catalan city of Manresa in the 14th and 15th Centuries: A political, social, and economic history (University of Toronto, 2005); Manuel SÁNCHEZ MARTínEZ stresses we still need studies on the effects of raising taxation on social relations; see "La fiscalidad real en Cataluña (siglo XIV)," Anuario de Estudios Medievales 22 (1992) pp. 341-377: 351-352. 
to buy grain for a family of five for one year). ${ }^{26}$ Jaume II also sold parts of the royal patrimony in order to raise funds for the Sardinian war. He sold cities, castles, jurisdiction, and revenues to raise about 663,000 sous. This led to a drop in royal revenue from 154,000s between 1320-1324 to 59,000 sous between 1330-1339. ${ }^{27}$ Cities and aljamas would become the Crown's main source of revenue.

In order to guarantee these contributions, King Pere authorized communities under his jurisdiction to collect taxes and borrow money. ${ }^{28}$ Until the early fourteenth century taxes were temporary measures to collect money for a specific event and the only form of credit was short-term loans. Taxes would increasingly become more permanent and were transferred to the jurisdiction of municipal governments. Cities small and large throughout the Crown of Aragon would increasingly collect taxes on property, income, commercial transactions, and consumption throughout the fourteenth century. When these proved insufficient, direct taxation, per capita, would be imposed mid-century. Called fogaje (a hearth tax), we have evidence that the first one was collected in Catalonia in 1358 and in Aragon in 1362 (not surprisingly, during the war with Castile).

Nevertheless, the money raised from taxation was not enough to satisfy demands from territorial lords, so cities and aljamas came to rely increasingly on the sale of censals and violaris to finance the deficits they

${ }^{26}$ Carlos Laliena Corbera, Historia de Aragón, ed. Eloy Fernández Clemente (Madrid: La Esfera de los Libros, 2008) p. 314.

27 SÁnchez Martínez, "La fiscalidad real en Cataluña," p. 360.

${ }_{28}$ Medievalists have paid much attention in recent years to the development of stable tax systems, which has been attributed in large part to growing fiscal demands of rulers engaged in wars of expansion. See Pere Ortí Gost and M. Sánchez Martínez, "La corona en la génesis del sistema fiscal municipal en Cataluña (1300-1360)," in Col-loqui Corona, Municipis i Fiscalitat a la Baixa Edat Mitjana (Lleida: Institut d'Estudis Ilerdencs, 1997) pp. 233-278; reprinted in Manuel Sánchez Martínez, ed., Pagar al Rey en la Corona de Aragón durante el siglo XIV: estudios sobre fiscalidad y finanzas reales y urbanas (Barcelona: Institució Milà i Fontanals, 2003) pp. 379-425; for Valencia, see Antoni Furió, "Estructures fiscals, pressió tributaria i reproducció economica al País Valenciá en la Baixa Edat Mitjana," in Col-loqui Corona, Municipis i Fiscalitat a la Baixa Edat Mitjana (Lleida: Institut d'Estudis Ilerdencs, 1997) pp. 495-526; See also Pere Verdés PIJuAn, "La consolidació del sistema fiscal i financer municipal a mitjan segle XIV. El cas de Cervera," in Fiscalidad real y finanzas urbanas en la Cataluña medieval, ed. Manuel SÁNCHEZ MARTínez (Barcelona: Institució Milà i Fontanals, 1999) pp. 185-217. 
incurred. ${ }^{29}$ The censal was a contract of sale in which the seller sold the right to collect a pension or annual income against capital given by the buyer. In other words, the lender bought the right to a pension from the borrower. This form of loan offered many advantages over the short-term loans that had previously dominated the credit market, such as a low interest rate - as low as 5-6\% in some cases, usually around 7-8\% - and long term repayment schedules. Since the principal did not have to be paid back until the borrower was ready to settle, the censal quickly became a useful tool for debt consolidation. ${ }^{30}$ The violari was distinct from the censal in that it had a set limit of one to two generations and thus slightly higher interest rates. As was the case in Valencia and Catalonia, fiscal pressure from the king led to the development in the Kingdom of Aragon of a municipal tax system and the increasing reliance on the sale of censals. ${ }^{31}$ In Zaragoza, the earliest censal on record was sold by the Jewish aljama to a local nobleman. ${ }^{32}$ By the mid fourteenth century, it had become impossible for municipalities or aljamas to bear royal demands without the censal.

The fiscal situation for the Jews was even more complicated since they traditionally contributed annual taxes to the Crown in exchange for royal protection and the right to practice their religion. It was to Jewish and Muslim communities living in royal lands that the Crown traditionally turned for any emergency levy. In the Crown of Aragon, Jewish communities had to pay a fixed annual tax to the Crown, usually divided into two payments. This amount was altered only if a given Jewish com-

29 Jordi Morelló I Baget, Fiscalitat i deute públic en dues viles del Camp de Tarragona. Reus i Valls, segles XIV-XV (Barcelona: Institució Milà i Fontanals, 2001) p. 743.

30 Antonio Berenguer Galindo, Censal mort: historia de la deuda pública del concejo de Fraga: (siglos XIV-XVIII) (Huesca: Ayuntamiento de Fraga, 1998) p. 9; Morelló I BAgET, Fiscalitat $i$ deute públic, p. 758. The censal was first mentioned in Barcelona between 1330-1340. See Jaime VICENS VIVES, Evolución de la economía catalana durante la primera mitad del siglo XV (Palma de Mallorca: Diputación Provincial de Baleares, $1955)$ p. 20. Arcadio García SAnz, "El Censal," Boletín de La Sociedad Castellonense de Cultura 37 (1961) pp. 281-310.

31 See M. a Isabel FAlcón PÉrez, "Finanzas y fiscalidad de ciudades, villas y comunidades de aldeas aragonesas," in Finanzas y fiscalidad municipal (Avila: Fundación Sánchez Albornoz, 1997) pp. 259-273, esp. 267.

32 FAlcón Pérez, "Finanzas y fiscalidad," p. 267. 
munity had a marked change in its economic situation. In Huesca, Jews paid 6,126s each year in taxes (half at the feast of St John in June, and the other half in January) in the first half of the century. ${ }^{33}$ The king could supplement his income from his Jewish subjects by asking for subsidies or loans from them.

Historians of the Jewish community of Huesca agree that until about 1340 the town was marked by economic prosperity, to which local Jews contributed and from which they benefited. ${ }^{34}$ Jews owned land, and were active in trade. ${ }^{35}$ This situation began to change after midcentury. Prior to the Black Death and the revolt of the Union of 1348, the Crown had already established a pattern of demanding subsidies from Jewish aljamas for its various military campaigns. ${ }^{36}$ In addition to paying subsidies for war, the Jews regularly had to contribute to other royal expenses such as weddings. With the drop in population after the Black Death, the burden of these demands increased on a per capita basis. In this period, King Pere increasingly passed on expenses to municipalities as well as Jewish and Muslim communities. In addition to help footing the bill for improving city fortifications, for example, the Jews of Huesca had to contribute 2,000lb in 1363 to help King Pere fight the war with Castile. ${ }^{37}$ This fiscal burden was not limited solely to the Jews. Aragonese cities involved in the revolt of the Union were heavily fined by the Crown. In addition, they had to pay high subsidies to fund the Sardinian campaign. Huesca, for example, had to pay at least $46,000 \mathrm{~s}^{38}$ The following decades offered no respite as Aragonese communities suffered the brunt of the war with

33 Del Arco, "La aljama judaica de Huesca," p. 281.

34 Del Arco, "La aljama judaica de Huesca," pp. $280 \mathrm{ff}$.

35 Durán Gudiol, La judería de Huesca, pp. 34-35.

36 See Yom Tov Assis, Jewish Economy in the Medieval Crown of Aragon, 12131327: Money and Power (Leiden-New York: E.J. Brill, 1997) pp. 161-172.

37 In 1354 Jews and Muslims from Huesca were ordered to contribute to the establishment of a Estudio General in Huesca until it could be supported by the municipality alone. The amount was not negligible - 1500s/year. Other expenses includes the cost of repairing 17 albacares in 1359 (city had to fix walls and other fortifications; Muslims, Jews, and Christians negotiated how much each community would pay and in 1363 - 2,000 lb jaquesas for war with Castile). Del Arco, "La aljama judaica de Huesca," pp. 281-285.

38 Laliena Corbera, Historia de Aragón, p. 280. 
Castile that marked much of the 1350s and 1360s. Since most of the war happened on Aragonese territories, many cities emerged out of the conflict ravaged and their commercial activity was severely disrupted. ${ }^{39}$

The royal policy of increasing taxation proved disastrous for many communities and the royal chancery records are filled with requests by cities and aljamas for moratoria or requests for new sources of revenue. Even sensible and efficient monarchs, such as Pere the Ceremonious, granted and cancelled those moratoria in often erratic ways. ${ }^{40}$ By the 1370s, the aljama of Huesca had to pawn some of its precious goods such as religious artifacts to be able to pay what it owed to the king. ${ }^{41}$ In 1380 , the community was expected to contri-bute 250 gold florins for the wedding of Prince Joan and the Queen of Castile. ${ }^{42}$ The following year the aljama declared itself unable to meet its commitments to pay a censal they had owned to the late Queen Leonor and which her son, Prince Martí had inherited, because of "great burdens" to which it was subjected, finding itself "at the point of becoming depopulated."

These pressures led many Jews to leave the city, which only exacerbated tensions within the aljama since the amount of taxes the aljama had to pass to the king remained the same. During Baruch's tenure as adelantado and tax collector some Jews complained that the aljama continued to demand taxes from them despite having established residence elsewhere. One example of that is the case of Sento Cogombrell, a tanner who left Huesca in the 1370s with his wife, children, and younger brother, in search of a better job. Despite having set up residence in Zara-

39 Laliena Corbera, Historia de Aragón, p. 283. The monarchs of the Crown of Aragon routinely had to plead for special subsidies from the Cortes. See José Luis MARTín, "Las cortes catalanas en la guerra castellano-aragonesa (1356-1365)" in VIII Congreso de Historia de la Corona de Aragón: La Corona de Aragón en el siglo XIV, t. 2, vol. 2 (Valencia, 1970) pp. 79-90.

40 See Guerson, "Coping with Crises," pp. $72 \mathrm{ff}$.

41 Del Arco, “La aljama judaica de Huesca,” p. 285.

42 The amount had to be reduced to 200 because the community could not pay; see ACA C 811: 115v, 116r-v (04/10/1380).

43 ACA C 820: 97v-98r (22/03/1381): "grans carrechs a que es tenguda sa posada en punt de despoblarse." The king answered with the order that the censal be paid from the taxes the aljama normally had to pay. 
goza, Sento complained to the king in December of 1381 that the administrators of the aljama of Huesca wanted to make him and his brother pay taxes there. This was the same year that the aljama declared itself unable to meet its obligations to Prince Martí. ${ }^{44}$ In cases such as these, royal officials re-affirmed the principle that individuals should not be taxed in two places at the same time. ${ }^{45}$ That Sento and his family were not the only ones leaving is clear from continuous complaints by the aljama (perhaps by Baruch himself?) that individual Jews were moving to other places so they could evade paying taxes to the aljama. ${ }^{46}$ Jews who stayed in the city complained they were overtaxed by the aljama. ${ }^{47}$ In the end, it is not surprising that the tax collector ended up murdered. That the problem was not just Baruch, is clear from the fact that many of these complaints continued after his death.

The fiscal situation of Jews in the Kingdom of Aragon was made worse during Prince Joan's tenure as governor general. In 1382, the year after the aljama of Huesca declared itself unable to meet some of its financial responsibilities, King Pere had to interfere when he found out his son was collecting too many subsidies and taxes from the aljama. ${ }^{48} \mathrm{He}$ had been told that officials acting in the name of Prince Joan collected 2,000 gold florins from the aljama of Zaragoza and large amounts from other Aragonese aljamas, which prompted the king to send a direct letter to his son ordering him to refrain from doing so under threat of penalty from the Crown. ${ }^{49}$ By 1385, the year Baruch was murdered, King Pere had promised the aljamas of Aragon a break from extraordinary demands but had to continue to reprimand Prince Joan's officials for harassing the Jews for subsidies and taxes. ${ }^{50}$

44 ACA C 820: 97v-98r (28/03/1380).

45 ACA C 815: 167r-168r (21/12/1381): "nullus teneatur nec astringitur in duobus locis contribuere nec peytare maxime in locis ubi non fovet suum incolatum."

${ }^{46}$ See, for example, ACA C 817: 122r-v (19/07/1381) and 1830: 184v-185r (04/02/1387).

47 ACA C 834: $11 \mathrm{r}(16 / 12 / 1383)$.

48 ACA C 826: 124v (19/07/1382).

49 ACA C 826: 125r (19/07/1382).

50 ACA C 842: 171v-172r (10/03/1385). This was not the first time King Pere had to admonish his son about the way he dealt with his Aragonese community. In 1377 Prince 
Internal conflict continued after Baruch's murder. His enemies did not take long to go after his children, filing suits against the minors for alleged administrative irregularities done by Baruch. When Baruch's brother protested, King Pere was quick to rule that Baruch's children should not be held responsible until an audit was done of their father's administration of the aljama. ${ }^{51}$ The king also clarified earlier that Baruch's children should not have to pay more taxes than their father. ${ }^{52}$ Prosecution of Baruch's murderers would itself become a bone of contention between Baruch's family and the aljama. Since Baruch was murdered while performing his duties as an official of the aljama, his family claimed the aljama should pay the costs of prosecuting his murderers, which, judging by the ill will against Baruch in some circles within the aljama, was easier said than done. As early as April of 1385, King Pere ordered the aljama to bear the costs of the trial of Baruch's murderers and he ordered so specifically because Baruch was killed "in the service of the aljama." ${ }^{33}$ By August of 1385, King Pere had to once against write a letter to the treasurer of the aljama to reiterate the previous order since it had been ignored. ${ }^{54}$ The unpopularity of Baruch's family was such that the aljama tried to cancel a tax collection concession that had been issued to Baruch's brother Isaac for a period of seven years, alleging that there was great "hatred" for him among certain individuals within the aljama. ${ }^{55}$

The late 1380s proved particularly trying times for the aljama of Huesca. A series of letters issued in 1388 shows that the problems of the early

Joan proved far too eager to prosecute a number of Jews from the community of Huesca of host desecration.

51 ACA C 843: 125r-v (05/08/1385).

${ }_{52}$ ACA C $842: 159 \mathrm{v}(10 / 04 / 1385)$. The issue of the degree of responsibility of underage children for actions of their parents often came up before the royal court. In 1383, the royal court reprehended the merino of Zaragoza for selling property belonging to the underage children of Sento Fateix of Zaragoza to pay for debt owed by their father. See ACA: 837: 40r-v (22/10/1383).

53 ACA C 842: 194r (15/04/1385): “... interfectus in servicio dicte aljame, vacando et solicite intendendo circa bonum publicum ipsius ...”.

54 ACA C 843: 125v-126r (05/08/1385).

55 ACA C 848: 8r-v (30/01/1386). The attempt did not work as the court confirmed the appointment. More research needs to be done on the period after 1391 to see what happened to Isaac Alentienz. 
1380s continued to be felt. The aljama continued to complain, for example, about individuals moving out of the aljama to seigneurial lands. ${ }^{56}$ In response, King Joan's officials, acting in the name of the king, instructed aljama officials to issue alatma and niduy - bans imposed by the community - in the synagogue against all those who had left the aljama in the past four years. ${ }^{57}$ Declaring alatma and nitduy against a malefactor was one of the harshest punishments available to aljama officials, although sometimes aljama officials would impose the death penalty for malshinut or corporeal punishment for other crimes. Although banishment does not seem like a harsh penalty against someone who has already left, the purpose here was probably to shame those who had abandoned their communal obligations and dissuade others from doing the same. It would also prevent individuals from transferring all their property to a place outside the city.

If the Jews of Huesca felt they could ease some of the pressures placed upon them by removing the tax collector, they quickly discovered that shooting the messenger did not alter the message. Such pressures did not ease with the murder of Baruch Alentienz, on the contrary. Another letter from 1388, for example, confirmed a remission of 1,000s per year for two years given to the aljama by King Pere in December of $1386 .{ }^{58}$ Attempts to improve aljama finances by awarding them new sources of revenue only soured the Jews' relationship with the city. When the aljama was allowed to collect taxes (sisa) on goods bought and sold within the aljama, they ran into trouble with municipal officials who had been in charge of collecting that specific tax in Huesca. ${ }^{59}$ Although usually municipalities could not tax Jews, in practice Jews often contributed to city coffers directly or indirectly. In this instance, since the city had obtained the right to collect the sisa in Huesca, municipal officials probably collected it from Jews as well. So when the king, perhaps somewhat thoughtlessly, granted to the Jews the right to collect that same tax within the Jewish community, it represented a loss of revenue for the city of Huesca, caus-

\footnotetext{
56 ACA C 1830: 184v (03/02/1388).

57 ACA C 1830: 184v (03/02/1388).

58 ACA C 1830: 186v-187r (04/02/1388).

59 ACA C 1830: 185r-v; King Joan confirmed the right to collect sisas in another letter issued a few months later - ACA C 1869: 74r-v (6/07/1388).
} 
ing a certain degree of tension in the city as the Jews rightfully claimed they could not be taxed twice.

Unfortunately, King Joan's attempts to ease the burden of taxes on the aljama of Huesca and prevent its depopulation, as the letters repeatedly affirm, were not consistent and more money was squeezed out when necessary. Less than a year after issuing a remission to the aljama of Huesca, King Joan ordered that the aljama contribute 6,000s a year to pay a stipend for a royal physician to whom King Pere had awarded 10,000s a year for his services. ${ }^{60}$ The two-year remission issued by the late King Pere had to be renewed in 1389 for another five years. ${ }^{61}$

In Aragon, most of the more acrimonious conflicts happened not in the principal aljamas such as Zaragoza or Calatayud but in medium-size or smaller communities such as those of Huesca and Alcañiz. There are many possible reasons for this. Despite being particularly hard hit by the Black Death, Zaragoza seems to have recovered somewhat by the late fourteenth century. Relatively few requests for moratoria on debts came from the Jewish community of Zaragoza, particularly when compared to other communities in Aragon or Catalonia. Of the requests for moratoria either by individual Jews or aljamas or complaints over moratoria given to debtors, only thirteen came out of Zaragoza in the 1380 s, compared to 119 from Barcelona. ${ }^{62}$ It is also possible that the aljama benefitted from the increasing migration from the countryside to the cities as well as from its key economic position both within the kingdom as well as for the Crown. In Zaragoza, the Jewish community was able to renegotiate its tax burden in the wake of the plague epidemic, making it an attractive place for Jews seeking employment, such as Sento Cogombrell, the tanner from

${ }^{60}$ ACA C 1835: 191r-192r (12/01/1389).

${ }^{61}$ ACA C 1894: 25r-v (01/07/1389).

${ }^{62}$ Recent research suggests that this may be due to the state of the economy in Aragon, which recovered earlier than Catalonia. Zulaica Palacios shows that by 1370s Aragon had reorganized its agricultural production towards the production of export crops such as saffron, wheat, olive oil, and wool. Taking advantage of the economic crisis in Catalonia, it forged itself as a financial centre. Fluctuaciones económicas en un período de crisis: precios y salarios en Aragón en la Baja Edad Media (1300-1430) (Zaragoza: Institución "Fernando el Católico," 1994) pp. 60-61. Financial documentation for this period is somewhat thin and needs to be taken carefully. It does, however, help explain why there were fewer cases of debt in Zaragoza. 
Huesca who relocated to Zaragoza seeking better opportunities. The attractiveness of larger cities increased pressure on smaller centers, which had population loss caused by plague exacerbated by emigration.

In many aljamas, fiscal and economic pressures contributed to rising conflict between individuals and the aljama administration. We have already seen how in Huesca, Jews focused their frustrations on aljama officials. Often, internal conflict led individual Jews to seek residence elsewhere. The decision to abandon family, friends, and one's hometown was not an easy one to take but if the point was to leave the aljama's jurisdiction, the decision was easier in the cases when a city had more than one aljama. One example is Alcañiz, which housed at least two Jewish communities. In 1179, King Alfons had awarded to the Order of Calatrava the castle in the city, making it one of its central seats in the Kingdom of Aragon. ${ }^{63}$ In either 1304 or 1307 King Jaume II awarded to the order of Calatrava the right to settle thirty Jewish households in Alcañiz and in 1324 he extends this privilege in perpetuity. ${ }^{64}$ In 1342, King Pere the Ceremonious, sensitive to the fact that the Jewish community in Alcañiz had been growing and some confusion had arisen in distinguishing between the original thirty households that belonged to the Order of Calatrava from the Jews who belonged to the royal treasury, extended the order's jurisdiction to all the Jews of Alcañiz for the lifetime of the its master, Alfonso Pérez. ${ }^{65}$ In recognition of the order's support during the war with Castile, King Pere awarded its master another thirty Jewish households between 1357 and 1376, although not in perpetuity. ${ }^{66}$ Since the 1342 privilege had expired with the death of Alfonso Pérez, it seems that by 1380 , the reality was that there were at least two jurisdictions competing for control of the Jews of Alcañiz: some belonged to the Order of Cala-

63 "Alcañiz" in Gran Enciclopedia de Aragón.

${ }^{64}$ Carlos Laliena Corbera, "Orígenes y extinción de una aljama judaica: Alcañiz, 1280-1414,” in Destierros aragoneses. I. Judios y moriscos (Zaragoza: Institución "Fernando el Católico," 1988) pp. 115-126: 117. Laliena has found two documents — one dates this event in 1304 and the other in 1307. AHN OO.MM., 435/287 dates the grant to the Order of Calatrava to 03/04/1304 and ACA C 204: 9r dates it to 03/03/1307.

65 Laliena Corbera, “Orígenes y extinción,” p. 118.

${ }^{66}$ Laliena Corbera, “Orígenes y extinción,” p. 118. 
trava while others, especially those who had moved from other places, fell under royal jurisdiction. A separate aljama was set up and the fact that the two communities shared the same space meant that for Jews in trouble within their aljama, crossing jurisdictional boundaries could not be easier. Much harder, however, was solving the conflicts that ensued.

A case in point was that of Mayl Avencuerna, a Jew who belonged to the original thirty households awarded to the master of Calatrava. At some point in the late 1370s and early 1380s, claiming he was "oppressed" by aljama administrators, Mayl moved himself and his goods to the royal aljama in the same city. It is unclear whether Mayl asked for permission from local representatives of the master of Calatrava to leave; either way, Jewish officials from his original aljama did not recognize his move and sought to collect taxes from him. In 1381, officials from the aljama under the Order of Calatrava succeeded in confiscating several of Mayl's goods, selling them in order to pay the taxes he allegedly owed to the aljama. It was at this juncture that Mayl appealed to the royal court, claiming that the adelantados of the aljama were acting unlawfully against him since he did not owe them any money and he now contributed with the Jews of the royal aljama. ${ }^{67}$ Initially, royal officials instructed the justice of Alcañiz and the vice-governor of Aragon to adjudicate the case, but about two weeks later, perhaps provided with new information, they more forcefully sided with Mayl ordering the master of Calatrava and the justice of Alcañiz to curb any attempt by the order's Jewish aljama to proceed against Mayl Avencuerna. ${ }^{68}$ The conflict would not end there, however, and five years later we find Mayl still in court against the adelantados of his former aljama, whom he accused of fabricating false documents against him. ${ }^{69}$ Interestingly, by then Prince Joan would have removed the Jews of Alcañiz from the order of Calatrava, alleging that this concession was supposed to last only during the lifetime of the master Alfonso Pérez (1336-1346), which was not the case for the original 30 households that

\footnotetext{
67 ACA C 814: 106r-v (04/02/1381); 108r (09/02/1381).

${ }^{68}$ ACA C 816: 144r-v (19/02/1381).

69 ACA C 856: 87r (03/03/1386).
} 
had been ceded in perpetuity, but in practice this order meant that all the Jews of Alcañiz now contributed to the royal treasure. ${ }^{70}$

Although it is impossible to know whether Mayl Avencuerna in fact owed money to his former aljama before he decided to move, he was not unique in complaining about the actions of aljama officials, particularly when it involved tax collection. Wealthy Jews particularly or those with connections in the royal household did not hesitate to protest the amount they were expected to contribute annually. As we have seen above, Baruch Alentienz's conflicts with the Jews of Huesca began when he refused to pay his portion of taxes alleging he was being overtaxed. Although he was unable to evade paying his taxes, others had better luck and had their complaints heard by the king; for example, royal officials sided with Mestre Mosse del Portal, physician of the queen, when he protested that he was being taxed excessively. ${ }^{71}$ Another physician, Jucef Bonafos, complained that the aljama of Vilafranca del Penedes tried to compel him to pay taxes there because he stayed in l'Arboç for a while on business. Jucef claimed that his family and his residence were in Barcelona. ${ }^{72}$ In the case of Mosse del Portal, officials reminded the aljama administrators that although it was their right to tax members of the aljama, they should do so with justice.

The complaint of being over-taxed was a common one in both Catalonia and Aragon, where individual Jews may certainly have had reasons to protest ever increasing taxes. Although the sources do not allow us to estimate exactly how much each Jewish family was taxed or to determine whether they were over-taxed, the drop in population after the Black Death followed by increasing fiscal demands from a Crown with growing international ambitions no doubt drove many within Jewish communities to seek ways to evade paying taxes either by moving themselves or their goods to other jurisdictions. Debt would also drive some to seek conver-

70 Laliena Corbera, “Orígenes y extinción,” pp. 119ff. See also ACA C 936: 72r-v (15/02/1381), and 72v-73r (14/02/1381).

71 ACA C 847: 61v62r (30/11/1385).

72 ACA C 852: 147v-148r (12/09/1386). 
sion in hope of getting out of debt and/or gaining access to Christian charities. $^{73}$

Nevertheless, the situation for Jewish officials was equally difficult. Jewish officials throughout Catalonia and Aragon constantly complained that individual Jews were refusing to pay their share of taxes. In 1382, for example, the aljama of Tárrega complained that individual Jews refused to contribute. ${ }^{74}$ In Calatayud, the problem was individual Jews who, having been chosen as judges of the community, ruled in their own favour making themselves exempt from contributing with the other members of the community. ${ }^{75}$ In both cases King Pere ordered the local bailiff to compel the recalcitrant taxpayers to fulfill their obligations, reminding those of Calatayud that "no one can excuse themselves from communal obligations." ${ }^{76}$ In doing so, King Pere safeguarded his own fiscal interests while also supporting aljama officials in their efforts to force recalcitrant taxpayers to pay. The crown generally walked a fine line between protecting individual Jews from being overtaxed and upholding aljama officials' authority in order to secure its own revenue. Nevertheless, the practice by successive kings of showing favour to individual Jews by awarding them with taxexempt status exacerbated tensions within Jewish communities in a time of growing debt and fiscal crisis.

In November of 1381, some individuals from the aljama of Zaragoza, described as being of the worse sort ("condicionis pessime"), placed false accusations against two families (Alatzar and de la Cavalleria) because of their tax-exempt status. ${ }^{77}$ While the letters are frustratingly opaque on the details of the conflict, it is clear from the series of letters about it that relations between the two families and the aljama had become quite difficult. The mistrust reached a point that the Alatzar and de la Cavalleria requested that conflicts between them and their fel-

73 See Alexandra Guerson, "Seeking Remission: Jewish Conversion in the Crown of Aragon, c.1378-1391” Jewish History 24 (2010) pp. 33-52.

\footnotetext{
74 ACA C 827: 80v-81r (10/09/1382).

75 ACA C 818: 147v-148r (09/09/1381).

76 ACA C 818: 147v: "ab onere comuni nemo se potest excusare."

77 ACA C 938: 192v-193v (07/11/1381).
} 
low co-religionists be adjudicated by Jewish officials only if a Jew of similar tax-exempt status could be appointed as one of the judges since "the whole aljama hates the francos [tax-exempt Jews] and the berurim [Jewish judges] belong to the aljama." ${ }^{78}$ The Alatzar and the de la Cavalleria families had always served as judges in the aljama and wanted to ensure they would continue to do so, especially now that they were more likely to be caught in legal conflict with the aljama. Interestingly, the Jews of Zaragoza used an accusation of malshinut against the two families to attempt to expel them from the aljama by issuing a sentence of alacme against them. ${ }^{79}$

Other cases involving tax-exempt (franco) Jews show that aljama officials often tried to tax those who held tax-exempt status. Benay Frances, his wife and children were granted tax-exempt status for life by the aljama of Zaragoza under pressure by Queen Leonor in 1366 but in 1380, Benay's widow, Giva, complained to the king that the adelantados of Zaragoza were trying to force her to contribute to the aljama's taxes. ${ }^{80}$ King Pere ordered the adelantados to observe the family's fiscal privileges, which had been given for life, and charged the merino of Zaragoza to ensure that the aljama complied. While the king's interference seems to have bought Giva and her children some respite, it did not prevent the aljama from trying again after a few years. We find Giva once again appealing to the king in 1389 for exactly the same reason. This time, King Joan not only ordered the adelantados to respect

\footnotetext{
78 ACA C 822: $153 \mathrm{v}-154 \mathrm{r}(28 / 10 / 1381)$.

79 Malshinut was the crime of informing against a fellow Jew to a non-Jewish court of law. For recent discussion of it see Mark D. Meyerson, "Revisiting the wax-press affair in Morvedre (1326-27): Jewish fiscal politics in the Kingdom of Valencia," in Jews, Muslims, and Christians in and around the Crown of Aragon : Essays in honour of Professor Elena Lourie, ed. Harvey J Hames (Leiden: Brill, 2004) pp. 303-320; Elena LouRIE, "Mafiosi and Malsines: violence, fear and faction in the Jewish aljamas of Valencia in the fourteenth century," in Crusade and colonisation: Muslims, Christians, and Jews in Medieval Aragon (Variorum, 1990) pp. 69-102. Both the Alatzar and the de la Cavalleria families had been for long vassals of the order of the Hospital of Saint John of Jerusalem. See Asunción Blasco Martínez, "Franquicia perpetua otorgada por la aljama de Zaragoza a favor de un matrimonio judío en 1366," in Judaísmo Hispano: estudios en memoria de José Luis Lacave Riaño, ed. Elena Romero, vol. 2 (Madrid: CSIC, 2002) pp. 537-548: 538.

80 ACA C 813: 78r (11/02/1380). See ACA C 825: 17v-18v (23/11/1381) which seems to suggest a tax issue related to this conflict.
} 
the franquitas given to Giva and her family but also threatened a fine of one hundred gold florins if the aljama should be found in breach of the privilege given to Giva. ${ }^{81}$

Despite Giva's protests, the aljama of Zaragoza was acting well within its rights when it proceeded against her in 1380. In 1379, in response to aljama officials' complaints, King Pere revoking the tax exemptions he had given to the Jews of Zaragoza. ${ }^{82}$ Despite the fact that Giva's benefactor, Queen Eleanor, had died in 1375, Giva seems to have continued to count with the support of the royal household as she effectively secured an exception from King Pere's cancellation of tax-exemptions. ${ }^{83}$

Tensions caused by increased taxation were not only within Jewish communities but also between them - usually involving the main community of a collecta and its members. Each Jew belonged to an aljama, which itself belonged to a wider grouping known as a collecta, which typically included a large Jewish community and smaller Jewish aljamas in its outlying areas. ${ }^{84}$ Such conflicts were more frequent in Aragon, where a collecta system was less fixed than in Catalonia. ${ }^{85}$ During much of first half of the 1380s, the Jews of the small community of La Almunia de Doña Godina, under the jurisdiction of the Knights Hospitallers, refused to contribute with the aljama of Calatayud, to whose collecta it belonged. ${ }^{86}$ In 1385 the king once more ordered the Jews

81 ACA C 1838: 32v-33r (01/02/1389). For more details on the tax-exempt status of this family, see Blasco Martínez, "Franquicia perpetua," cited above.

82 Blasco Martínez, "Franquicia perpetua," p. 544.

83 It was not the first time Giva secured an exception of this kind. In 1367, King Pere revoked the exemptions he had given and Giva ensured this cancellation did not apply to her own status. See Blasco Martínez, "Franquicia perpetua," p. 542.

84 For a detailed explanation of the collecta system in the Crown of Aragon, including Roussillon and Valencia, see Assis, The Golden Age of Aragonese Jewry, pp. 179-196; Jewish Economy, pp. 183-205.

85 For the collecta system in Aragon, see Assis, Jewish Economy, pp. 200-204.

86 ACA C 830: 133v (01/06/1383) includes a letter from 1378 that lists La Almunia de Doña Godina, alongside Ricla, Fariza, Arandiga and other communities around Calatayud as belonging to its collecta. 
of La Almunia to pay its contributions to Calatayud. ${ }^{87}$ Likewise, the small communities of Caspe and Maella were locked in conflict with the larger community of Alcañiz throughout the 1380s. In 1385, Caspe had secured a privilege from King Pere making it a separate aljama and placing Maella under its fiscal jurisdiction, although traditionally both Caspe and Maella had belonged to the collecta of Alcañiz. ${ }^{88}$ Despite the privilege issued to the Jews of Caspe and Maella, the aljama of Alcañiz would continue to press them for contributions and representatives of the two aljamas would go back and forth to the royal court over the following few years over the issue. There seems to be some evidence that less than a year later, King Pere revoked the privilege it had given to Caspe although officials did not give up trying to secure their fiscal independence from Alcañiz. ${ }^{89}$ Alcañiz had earlier been in a similar conflict with the Jews of the Castellania de Emposta, in the archbishopric of Zaragoza. ${ }^{90}$ Similar conflicts would also pit the Jews of Teruel and Albarracín against each other a few years later. ${ }^{91}$

It is important to stress, however, that the fiscal pressure monarchs imposed on the Jews of the Crown of Aragon in the late fourteenth century was not of the same nature as the exploitation imposed by English or French monarchs on their Jews in the thirteenth century. In midthirteenth-century England, for example, King Henry III ordered a full investigation of Jewish wealth in his kingdom. Once this information was gathered he ordered a massive tallage of English Jewry, with disastrous consequences. In the words of Robert Stacey, an expert on the finances of Henry III, this tallage "ruined the Jewish magnates of England, and effectively decapitated the class structure of medieval Anglo-

87 ACA C 945: 98r-99v (10/06/1385).

88 See ACA C 945: 100r (10/06/1385); ACA C 853: 63r-v (18/08/1386); ACA C 855: 67v-69r (05/07/1386).

89 In 1398, representatives of the Jewish communities of Caspe and Maella presented to King Martí the original privilege issued by King Pere in 1385, asking him to confirm it. After looking into the matter, King Martí decided to maintain the connection among the three communities. It would not be until King Fernando I, in 1412, that Caspe and Maella would be able to confirm their separate status. See LaLiena Corbera, "Orígenes y extinción," p. 121.

90 ACA C 936: 128v (26/03/1381).

91 ACA C 1839: 55v (01/03/1389). 
Jewry. By so doing Henry broke the financial backbone of the English Jewish community, and permanently reduced its value to the Crown." Both King Pere and King Joan accepted that there were reasonable limits to how much they could squeeze from their Jewish communities. Although Joan had shown less restraint when heir to the throne, he maintained his father's more conciliatory and pragmatic policies when he became king. ${ }^{93}$ King Pere was often aware that there were limits to how much he could expect from any given community as the recurring grants of moratoria have shown.

Here is where reading the history of the Jews alongside the history of the wider community in which they lived is crucial. What we see in the Crown of Aragon in the late 1380s is not a changing policy regarding Jews specifically. Fiscal changes affected all who lived in Crown territories. Cities throughout Catalonia and Aragon were suffering similar fiscal pressures in this period. ${ }^{94}$ Jewish and Christian communities adopted similar responses to deal with these similar pressures by engaging in public debt financing. The network of debt became ever more intertwined in this period. At the top, the king would borrow money via the sale of censals and would often use a Jewish community's revenue as collateral. In many cases, it was common for the king to simply pass the censal itself to a Jewish community by commuting a tax that the community previously paid to the king into responsibility

${ }^{92}$ Robert C. STACEY, Politics, policy, and finance under Henry III, 1216-1245 (New York: Oxford University Press, 1987) p. 154; see also Robin R. MundiLl, The King's Jews : money, massacre and exodus in Medieval England (London: Continuum, 2010) pp. 151ff. The Jews of northern France were equally exploited by successive monarchs in the thirteenth century. See Robert Chazan, The Jews of Medieval Western Christendom, 1000-1500 (Cambridge: Cambridge University Press, 2006) p. 142. See also Sophia Menache, "The King, the Church and the Jews: some considerations on the expulsions from England and France," Journal of Medieval History 13 (1987) pp. 223-236.

${ }^{93}$ It is unclear whether this was a conscious decision by the king or the result of the bureaucratization of royal administration. Many of the day-to-day decisions regarding a majority of cases to reach the royal court were made by officials acting in the name of the king rather than the monarch himself.

${ }^{94}$ BAER noted that in King Pere's reign, "taxes were as oppressive for the Christian municipalities as for the Jewish aljamas." See A History of the Jews in Christian Spain, vol. 2, p. 31. See also Fynn-Paul, "Civic debt, civic taxes," and The Catalan City of Manresa. 
for a censal. In 1380, for example, the crown had obtained 154,000 s through the sale of a censal, for which it would have to pay $11,000 \mathrm{~s}$ annually. ${ }^{95}$ The king also owed 2,000s to one Miguel Cosell. Instead of paying these debts directly out of royal revenue, King Pere passed on the obligation to the Jews of Barcelona replacing the 13,000s in annual taxes (quaestia) that the aljama owed to the crown. ${ }^{96}$ As a result, more and more of an aljama's revenue was used to finance debt, as we saw before.

Jordi Morelló i Baget has recently published a very detailed fiscal study of two cities in the hinterland of Tarragona between the thirteenth and fifteenth centuries. Although he focused exclusively on the development of fiscal and financial institutions in the fourteenth century, leaving aside the crucial topic of the consequences of bankruptcy and fiscal crisis on the population of the cities he studied, nonetheless his study is extremely valuable for understanding the background to the challenges facing urban dwellers in Catalonia in the late fourteenth century. ${ }^{97}$ Focusing particularly on the cities of Reus and Valls, Morelló i Baget traces how Catalan cities saw their fiscal obligations increase steadily during the twenty years prior to the war of the two Pedros and made ever worse during the last third of the fourteenth century. ${ }^{98}$ Morelló i Baget, like Sánchez and Ortí before him, saw the clear relationship between growing taxation and increasing debt in this period as communities tried to figure out how to produce the contributions demanded by the Crown. ${ }^{99}$ For our purposes here, the important factor to highlight is not only the parallel histories of Christian and Jewish communities in this period but perhaps even more relevant is

\footnotetext{
95 ACA C 1100:36v-37r (07/09/1380).

96 ACA C 1100:37r-v (07/09/1380).

97 Rural dwellers were by no means spared these pressures, which in Catalonia would lead to revolts in the countryside. See Paul H Freedman, The Origins of Peasant Servitude in Medieval Catalonia (Cambridge: Cambridge University Press, 1991).

98 Morelló i Baget, Fiscalitat i deute públic, pp. 164-167, and 170ff.

99 Morelló i Baget, Fiscalitat i deute públic, p. 299; Pere Ortí Gost, M. SÁnchez Martínez, and MaX Turull i Rubinat, "La génesis de la fiscalidad municipal en Cataluña," Revista d'Historia Medieval 7 (1996) pp. 115-134; SÁNCHEZ MartíneZ, "La fiscalidad real en Cataluña."
} 
to note the conflict over jurisdictions that such pressures engendered. Morelló i Baget highlights how increasing royal taxation in the Camp de Tarragona heightened conflict between the Crown and the Church, for example, in the 1370 s. ${ }^{100}$ Tarragona was the see of an archbishopric and the church had seigneurial jurisdiction in much of the area, including the right to tax its inhabitants. By taxing them directly, King Pere came into conflict with the archbishop. Some of these conflicts involved the Jews. In Huesca, for example, the local bishop tried to exact tithes from the Jews, much to the displeasure of King Pere. ${ }^{101}$

After 1350, the main elements of a tax system were in place in the form of tax collection institutions and stable forms of tax distribution. ${ }^{102}$ This would have an impact on Jews as well. Although the Jews were among special groups considered outside of municipal jurisdiction - an autonomous group within the city - alongside the clergy and knights, they were increasingly under pressure in the late fourteenth century to contribute more with the city. According to Morelló, in the second half of the fourteenth century, municipalities began to attempt expanding the number of contributors to city coffers by trying to include Jewish communities. In Tarragona, they began to appear in the tax collection records of the city. ${ }^{103}$ Many Jewish communities seem to have struck an understanding with the municipal government of the cities in which they lived. In Girona, for example, the Jews seem to have routinely paid a levy to city officials twice a year. ${ }^{104}$ In fact, the Jews of Girona seem to have contributed with the city for quite some time. In 1339 ,

\footnotetext{
100 Morelló i Baget, Fiscalitat i deute públic, pp. 194-195.

101 ACA C 814: 57v-58r (05/01/1381). The riots against Jews in 1391 would affect Tarragona. See BAER, A History of the Jews, vol. 2, p. 103.

102 Morelló i Baget, Fiscalitat i deute públic, p. 907.

103 Morelló I Baget, Fiscalitat i deute públic, p. 419; Morelló cites the case of the Jews of Belaguer, where city officials were able to reach an agreement with the Jews in which they (the Jews) would pay taxes over half of their goods to the city. See Montserrat Cases Nadal, "Els jueus de Balaguer en el llibre de l'Estima de 1412," in Col-loqui d'historia dels jueus a la Corona d'Aragó (Lleida, 1991) pp. 321-334: 323.
}

104 Guerson, "Coping with crises," 221-222. 
two wealthy members of the aljama of Girona, Bonjudà Cresques and his son-in-law Saltell Gracià, left 17,500 s to the city to fix walls. ${ }^{105}$

Although Jews would often voluntarily agree to contribute taxes to the cities in which they lived, disputes would arise over what precisely constituted a fair contribution. Often, the conflict with municipalities concerned less the issue of being taxed than of being overtaxed. In Tortosa, for example, Jews contributed to the building of the city's walls but complained that the amount they were expected to contribute far exceeded their ability to pay and caused many individual Jews to leave the city, a prospect that led the crown to consider a "great dammage to the aljama... and loss to our treasure." ${ }^{106}$ The Jews of Jaca, on the other hand, received less support from royal officials when they refused to contribute anything to the upkeep of the city's walls, something they had traditionally done in the past. ${ }^{107}$

The fiscal pressure imposed upon the Jews of the Crown of Aragon had implications far beyond the possible impoverishment of a given community. Perhaps more important than the purely economic effects of increased taxation were its effects within Jewish aljamas. We have seen the range of conflicts that tax collection could cause both within and between aljamas in the Crown of Aragon. Because of the way taxes were assessed and collected, aljama officials bore the brunt of their community's resentment over growing fiscal pressure. Conflict between individual Jews and officials would lead many Jews to move in order to reduce their tax burden. Those who had close connections

105 Sílvia Planas i Marcé, "La vida cotidiana en el call de Girona en siglo XIV: nuevas aportaciones documentales," in Juderías y sinagogas de la Sefarad medieval: en memoria de José Luis Lacave Riaño, eds. Eloy Benito Ruano, Ana María López Álvarez and Ricardo IzQuierdo Benito (Univ de Castilla La Mancha, 2003) pp. 253-291: 281.

106 ACA C 1270: 62v-64v (25/01/1381); 65r-v (10/02/1381): “in ipsius aljame et eius singularium damnum et prejudicium redundare... in dominucionem nostrarum regaliarum et iurium ...".

107 ACA C 817: 162r-v (20/08/1381); ACA C 823: 29r-v (01/09/1381). Other disputes involving contribution to the building or upkeep of city walls involve Tarazona (ACA C 817: 180r [02/09/1381]); Calatayud (ACA C 838: 33r-v (16/03/1384); Huesca (ACA C 1110: 26v-27r [16/11/1386]); and Fraga (ACA C 1831: 165v-166r [14/07/1388]) where Jews complained that city officials gave better deals to Christians than they did to Jews who found themselves unable to pay their share of contributions. 
to the Crown, as we saw, were sometimes able to find reprieve or even a tax-exempt status, much to the resentment of the rest of the community. Fiscal pressure was felt not only by individuals but also by the aljamas themselves as fiscal demands rose within a collecta, particularly in the Kingdom of Aragon, as we have seen. All these conflicts led to a steady deterioration of the authority of those who held power within Jewish communities. What we see time and again in the chancery registers is evidence of aljama officials using the king to shore up their authority within the community. Not only did individual Jews often refuse to pay their taxes but they also challenged the authority of aljama tax collectors, often with deadly consequences, as the case of Baruch Alentienz has shown us.

Recibido: 20/06/2014

Aceptado: 06/07/2015 